\title{
Analysis of the Impact of Economic Growth and Wages on Educated Unemployment in Indonesian Provincial Area
}

\author{
Saniatul Lativa ${ }^{1}$, Darwati Susilastuti ${ }^{2}$ \\ \{sanilativa13@gmail.com ${ }^{1}$, darwatisusi@borobudur.ac.id² \\ Universitas Borobudur, Jakarta, Indonesia ${ }^{1,2}$
}

\begin{abstract}
The high number of educated unemployed is one of the features of unemployment in Indonesia, however economic growth and earnings are increasing every year. This is troubling because, in theory, as the economy grows and incomes rise, unemployment should decrease, but it does not in practice. The motivation behind this examination is to investigate: 1) the effect of financial development on instructed joblessness, and 2) the effect of wages on taught joblessness. This form of study is done after the fact. The study focuses on 33 Indonesian provinces utilizing panel data. Documentation is a data collection tool. Panel data regression is used to test hypotheses. The findings of the study show something which: 1) Peconomic growth has a big negative impact on educated unemployment, 2) Wages have a significant positive impact on educated unemployment.
\end{abstract}

Keywords: Educated Unemployment; Economic Growth; Wages

\section{Introduction}

Joblessness is a reality looked by all nations, both creating and created nations. Unemployment is a macroeconomic problem thatinfluencedirectly and is a big problem because it will cause a decrease in living standards and psychological stress for the workforce [1]. The existence of unemployment will reduce people's productivity and income, which in turn will cause social problems in society. One of the qualities is that In Indonesia, the high number of educated unemployed is a source of unemployment. Unemployment among the educated is defined as someone who is employed. I've been looking for work but haven't been able to find anything that requires a high school education or comparable.(Lipsey, 1997; Tambunan, 2001) [2]; [3]; [1]; [4] (Pasay and Indrayanti, 2012; BPS, 2018). In developing countries, educated unemployment is a consequence of the role of supply factors (Bloom and Sevilla 2003).

Based on data unemployment, based on the level of education, it is known that the number of unemployed in 2015 was 7.56 million people, decreased in 2016 to 7.03 million people but in 2017 it increased again to 7.04 million people. Based on the number of unemployed, it turned out to be dominated by educated unemployment, namely 62.89 percent in 2015 and decreased to 60.56 percent in 2016 but in 2017 it increased again to 62.41 percent. Furthermore, based on the educated unemployment rate at each level of education, it is known that in 2015 the unemployment rate for those who graduated from SMK was $11.65 \%, 10.32 \%$ 
, $7.54 \% 7.54$ percent graduated from university, 6.40 percent from academy/diploma, and 6.40 percent from high school. With 8.72 percent having completed high school, 6.04 percent having completed an academy/diploma, and 4.87 percent having obtained a university degree, the unemployment rate for educated vocational school graduates was 11.11 percent in 2016. In 2017, educated SMK graduates had an unemployment rate of 11.41 percent, with 8.29 percent having completed high school, 6.88 percent having completed Academy/Diploma, and 5.18 percent having completed University. In 2018, the overall unemployment rate for educated people was 31.10 percent, with 11.24 percent of them jobless. of SMK graduates, 7.95 percent of high school graduates, $6.02 \%$ of Academy/Diploma graduates, and $5.89 \%$ of University graduates. (BPS, 2020).

According to accessible data, there is a situation in which the workforce of vocational school graduates In comparison to high school graduates who were not equipped to enter the work market, the number of high school graduates who were prepared to enter the labor market has grown. The next phenomenon is that many college grads are still unemployed (academics and universities). Of course, this will be a major challenge for Indonesian education, because a high degree does not guarantee a job. High amount unemploymenteducation in Indonesia faces a severe challenge, and significant efforts are required to overcome it. Of course, further research is needed to figure out what factors influence the amount of unemployed educated workers in Indonesia and what are the solutions in reducing the level of education in Indonesia. educated unemployment.

A country is said to be growing well or poorly, it can be seen through macroeconomic variables that are used as a measure of economic performance. These variables include economic growth, unemployment rate, and inflation [1]. The peculiarity of monetary development and joblessness is as yet a fascinating conversation to study, in light of the fact that there are nations or areas with high financial development, yet in addition high joblessness rates. The present circumstance set off the development of Okun's Law. As indicated by Okun's law, the connection among joblessness and financial development is conversely relative (negative), implying that the lower the joblessness rate, the lower the joblessness rate. As indicated by Okun's law, for each $2 \%$ fall in GDP, the jobless rate increases by $1 \%$ [5]. According to Denburg (1985), the lower the unemployment rate, the lower the rate of economic growth, and vice versa [6].

Notwithstanding financial development, compensation are one of the elements that influence joblessness. High wages can encourage work morale and labor productivity, so that it will cause the resulting production to increase, so that rising wages result in people offering labor to companies to increase, and unemployment to fall. But it can also be the other way around, rising wage rates cause companies to have a choice between using labor or using machines or technology. If to increase the same amount of production, the additional costs incurred by the company due to the additional use of labor will be higher than the additional costs due to the additional use of machines, then the company will reduce the amount of use of labor and unemployment will increase. Compensation will be pay gotten by a work unit as the measure of cash paid. Work compensation are vital for the two players. For makers, compensation are creation costs that should be diminished as effectively as could really be expected. For laborers, compensation are a kind of revenue for themselves, their families and a wellspring of local area consumption. High and low wages are significant variables that decide individuals' way of life. 


\section{Literature Review}

PEducated unemployment is defined as someone who, although having a high school education or equivalent, is actively looking for work but has yet to find it [1];[2]; [3]; [4]; (BPS, 2018). Unemployment is a fact of life in all countries, developed and developing alike. According to Mankiw (2010), unemployment is a macroeconomic issue that impacts humanity. directly and is a big problem because it will cause a decrease in living standards and psychological pressure for the workforce [1]. Taught joblessness is believed to be affected by financial development. Okun's law expresses that for each $2 \%$ lessening in GDPwillincrease the joblessness rate by $1 \%$ [5]. Denburg (1985) states that the higher the rate of economic growth, the lower the unemployment rate and vice versa [6].

Okun's law was tested by Soegner and Stiassny (2002), who found a negative link between unemployment and real GDP [7]. For three reasons, according to Moosa (2008), there is no connection among joblessness and yield in Algeria, Egypt, Morocco, and Tunisia [8]. (a) The unemployment that occurred was structural and/or frictional, rather than cyclical; (b) The rigidity of the labor market that exists in the four nations where the government is the main source of labor demand; and (c) The government-dominated economic structure..

Agifiand Malaj (2015) whoidentify the impact of economic growth on the unemployment rate in the Republic of Macedonia [9]. For the period 1998-2013 in the Republic of Macedonia, the data were evaluated using regression analysis and an economic growth model derived using the OLS (Ordinary Least Squares) approach. Unemployment has a considerable positive link with unemployment, according to the findings. Research conducted by Makun and Azu (2015) about Long-term relationship between growth and investment and unemployment in Fiji for the period 1982-2012. The study conducted a test using the cointegration test to ascertain the relationship between growth, investment and unemployment[10]. The test results prove that there is a long-term relationship between economic growth and investment with unemployment, with an increase in economic growth and investment will increase economic output so that unemployment will decrease.

Banda, et.al, (2016) conducted research on the Using quarterly time series data from 1994 to 2012, the effect of monetary development on joblessness in South Africa was inspected. A vector mistake amendment (VECM) model is utilized in this examination[11]. The findings of the VECM reveal that economic expansion has a long-term beneficial and considerable impact on unemployment. Schubert and Turnovsky (2017) investigated the relationship between growth and unemployment by incorporating wage negotiation into an endogenous growth model.[12] It was found that in the long and short term the unemployment rate is influenced by economic growth. Countries with high economic growth tend to reduce unemployment.

Study O'Nwachukwu and Increase (2017) From 1980 to 2016, the investigates the factors that influenced Nigeria's unemployment rate. The impact of government spending, inflation, population, and economic growth on the unemployment rate is investigated in this study model [13]. The Ordinary Least Squares (OLS) approach is used in this investigation. According to the findings of this study, changes in unemployment in Nigeria are influenced by government spending, inflation, and population. Economic development, on the other hand, was shown to have little statistical significance in explaining unemployment in Nigeria.

In a board information technique, Soylu et al. (2018) look on the connection between financial development and joblessness in Eastern Europe from 1992 to 2014 [14]. This relationship was investigated in the context of Okun's Law in this research. The Johansen Test Co-integration Panel, the Unit Root Panel, and the OLS Pooled Panel were all used. The findings reveal that economic growth and the stationary unemployment series in the first level 
are both positively influenced by economic growth, i.e., a $1 \%$ increase in GDP reduces unemployment.as big as $0.08 \%$.

Wages are remuneration provided by the company/organization to workers whose amount is initially agreed upon by both parties. Wages are usually set based on regional minimum wages, where minimum wages consist of: Minimum wages based on Province and Regency/City areas and Minimum Wages based on sectors in Province and Regency/City areas. Wages are divided into two, namely: minimum wages (amount of wages received) and real wages (amount of goods and services that can be purchased with the money wages).

Wages in a narrow sense are specifically used for workers who work for other people in an employment relationship (as employees or laborers) Gilarso (2007). "A negligible standard utilized by business people or industry players to offer wages to laborers in a business or workplace" is characterized as "a base standard utilized by business visionaries or industry players to give wages to laborers in a business or workplace" [15]. The major goal of establishing a minimum wage is to provide a minimal standard of living for the health, efficiency, and welfare of workers. workers. The minimum wage policy in Indonesia is contained in the Regulation of the Minister of Manpower, Kep Men Naker no. 17/2005 and Minister of Labor Decree no. 13/2012 and Manpower Law Number 13 of 2003. The lowest pay permitted by law as alluded to in the Regulation of the Minister of Manpower is the most reduced month to month wage comprising of fundamental wages including fixed remittances. This is an amount of compensation received by employees on a regular and regular basis, which is associated with attendance or certain achievements [16].

The basic assumption of classical economics is that the economy always exists in a state or condition of full employment. Namely that who wants to work will get a job and companies that need labor will get the desired amount. So the unemployed are people who are deliberately unemployed [17].

\section{Methodology}

The type of research is ex post facto. The object of research is 34 provinces in Indonesia. The Panel data is a sort of data that may be used to test hypotheses using panel data regression. The study's dependent variable is educated unemployment, whereas the independent variables are economic growth and inflation. and wages. Educated unemployment is the labor force of high school graduates and above who do not have a job and are actively looking for work which is measured in units of people. Economic growth is the rate of economic growth of each province in Indonesia as measured by constant price GRDP measured in rupiah. Wage is the regional minimum wage (UMR) in each provincial government in Indonesia which is measured in rupiah. The operational definition of each research variable can be seen in the following table.

Table 1. Operational Definition of Research Variables

\begin{tabular}{clclcc}
\hline No. & \multicolumn{1}{c}{ Variable } & Symbol & \multicolumn{1}{c}{ Definition } & Data Source \\
\hline 1 & $\begin{array}{l}\text { Educated } \\
\text { unemployment }\end{array}$ & Eu & $\begin{array}{l}\text { The labor force of high school } \\
\text { graduates/equivalent who do not have a } \\
\text { job and are actively looking for work } \\
\text { measured in units of people }\end{array}$ & $\begin{array}{c}\text { Central Bureau } \\
\text { of Statistics }\end{array}$ \\
2 Economic growth & eg & $\begin{array}{l}\text { The economic growth rate of each } \\
\text { province in Indonesia as measured by } \\
\text { constant price GRDP measured in rupiah }\end{array}$ & $\begin{array}{c}\text { Central Bureau } \\
\text { of Statistics }\end{array}$ \\
\hline
\end{tabular}




\begin{tabular}{ccccc}
\hline No. & Variable & Symbol & Definition & Data Source \\
\hline 3 & Wages & Wage & $\begin{array}{l}\text { The regional minimum wage (UMR) for } \\
\text { each provincial government in Indonesia } \\
\text { measured in rupiah }\end{array}$ & $\begin{array}{c}\text { Central Bureau } \\
\text { of Statistics }\end{array}$ \\
\hline
\end{tabular}

Hypothesis testing is done using panel data. The linear regression model using cross section and time series data is as follows. Model with cross section data:

$\mathrm{Yi}=+\mathrm{Xi}+\mathrm{i} ; \mathrm{i}=1,2, \ldots, \mathrm{N}$

$\mathrm{N}$ : the number of cross section data

Mode with time series data

$\mathrm{Yt}=+\mathrm{Xt}+\mathrm{t} ; \mathrm{t}=1,2, \ldots, \mathrm{T}$

$\mathrm{N}$ : the number of time series data

Considering that panel data is a combination of cross section data and time series data, the model is written as:

Yit $=+$ Xit + it $; \quad i=1,2, \ldots, N ; \quad t=1,2, \ldots ., \mathrm{T}$

Where :

$\mathrm{N} \quad$ number of observations

$\mathrm{T}=$ amount of time

$\mathrm{N} \times \mathrm{T}=$ number of panel data

The empirical model of this research is as follows:

euit $=+1$ egit +2 wageit +

Information :

eu $\quad=$ Educated unemployment

$=$ Constant

$=$ Regression coefficient

eg $\quad=$ Economic growth

wage $=$ Wages

$\mathrm{i} \quad=1,2,3, \ldots \ldots, \mathrm{N}$ (cross section dimension)

$\mathrm{t} \quad=1,2,3, \ldots \ldots, \mathrm{T}($ time series dimension)

$=$ Error term

To estimate model parameters with panel data, several techniques are offered, namely:

a) Ordinary Least Square. This method resembles Using cross-segment or time-series information to play out a relapse However, with board information, we should incorporate cross segment and time series information prior to doing a relapse (pool information). Then, at that point, utilizing the Ordinary Least Square (OLS) strategy, the pooled information is viewed as a solitary perception unit and used to appraise the model.

b) Fixed Effect Model. Because there are variables that aren't all included in the model equation, an intercept that isn't constant is possible. Or, to put it another way, this intercept 
may vary depending on the person and the time. This way of thinking provides the foundation for the model's creation.

c) Random Effect Model (Random Effect). If variations between people and/or time are expressed through intercepts in the fixed effects model, these differences are accommodated through errors in the fixed effects model. This method also accounts for the possibility of mistakes being connected across time series and cross sections.

Utilizing two model assessment methodologies, pick the ideal model among normal impacts, fixed impacts, and arbitrary impacts. In board information relapse, these two methodologies are utilized to see as the best model for assessing board information relapse. The Chow test was utilized to decide whether a typical impact or fixed impact model ought to be used. Second, in assessing board information relapse, the Hausman test is utilized to choose the best fixed impact or arbitrary impact model.

a) Chow Test

The Chow test compares the common effect model to the fixed effect model (Widarjono, 2009). The E-views program was utilized for the Chow test in this study. The following are the assumptions that were established during the Chow test:

H0: Shared Effect Model

Model with Fixed Effects (H1)

If the P-value is smaller than the value of a, $\mathrm{H} 0$ is rejected. If the P-value is greater than the value of a, however, $\mathrm{H} 0$ is accepted. The worth of a used item is $5 \%$.

b) Hausman Test

In order to choose the optimal model to utilize as a panel data regression model, this test contrasts fixed and random effects models (Gujarati, 2012). The Hausman exam use the Eviews program, which is comparable to the Chow test. The Hausman test generates the following hypothesis:

Random Effect Model (H0)

Model with Fixed Effects (H1)

If the P-value is smaller than the value of a, H0 is rejected. If the P-value is greater than the value of a, however, $\mathrm{H} 0$ is accepted. The worth of a used item is $5 \%$.

\section{Results and Discussion}

Testing the impact of monetary development and wages on instructed joblessness is finished by utilizing board information relapse examination. UTo acquire the right model in assessing the board information relapse, a test is first conveyed outChow and test Hausman.Chow test is a test to decide the proper impact model or normal impact generally fitting to use in assessing board information. The aftereffects of the Chow test information investigation are as per the following.

Table 2. Chow Test Results

Redundant Fixed Effects Tests

Equation: Untitled

Test cross-section fixed effects

\begin{tabular}{lccc}
\hline Effects Test & Statistics & df & Prob. \\
\hline Cross-section F & 75.718694 & $(32,262)$ & 0.0000 \\
Cross-section Chi-square & 691.145979 & 32 & 0.0000 \\
\hline
\end{tabular}

Cross-section fixed effects test equation: 
Dependent Variable: EU

Method: Least Squares Panel

Date: 12/20/20 Time: 12:06

Sample: 20102018

Periods included: 9

Cross-sections included: 33

Total panel (balanced) observations: 297

\begin{tabular}{lcccc}
\hline \multicolumn{1}{c}{ Variable } & Coefficient & Std. Error & t-Statistic & Prob. \\
\hline C & -166861.6 & 251898.4 & -0.662416 & 0.5082 \\
LOG(EG) & 114986.7 & 5706,398 & 20.15049 & 0.0000 \\
LOG(WAGE) & -75012.59 & 17688.46 & -4.240763 & 0.0000 \\
\hline & & & \\
R-squared & 0.582167 & Mean dependent var & 121364.6 \\
Adjusted R-squared & 0.579324 & SD dependent var & 175748.9 \\
SE of regression & 113989.9 & Akaike info criterion & 26.13566 \\
Sum squared resid & $3.82 \mathrm{E}+12$ & Schwarz criterion & 26.17297 \\
Likelihood logs & -3878.145 & Hannan Quinn Criter. & 26.15059 \\
F-statistics & 204.8148 & Durbin-Watson stat & 0.114365 \\
Prob(F-statistic) & 0.000000 & & \\
\hline & Source: Data processed output, 2021
\end{tabular}

The likelihood worth of cross area $\mathrm{F}$ and chi square is 0.00 dependent on the discoveries of the information examination for the chow test. The likelihood esteem $(0.000 .05)$ is not exactly alpha. The model with the proper impact method is known to be the ideal model for doing the investigation dependent on the results of this information examination. The Hausman test was then used to survey whether fixed impacts or arbitrary impacts were the ideal methodology. The accompanying table shows the aftereffects of the Hausman test.

Table 3.Hausman Test Results

Correlated Random Effects - Hausman Test

Equation: Untitled

Test cross-section random effects

\begin{tabular}{|c|c|c|c|c|}
\hline Test Su & & Chi-Sq. Statistics & Chi-Sq. df & Prob. \\
\hline Cross-secti & dom & 20.537337 & 2 & 0.0000 \\
\hline \multicolumn{5}{|c|}{ Cross-section random effects test comparisons: } \\
\hline Variable & Fixed & Random & Var(Diff.) & Prob. \\
\hline LOG(EG) & -76284645996 & 92371.666823 & 1674181438.913162 & 0.0000 \\
\hline LOG(WAGE) & 53004.279868 & -19060.854990 & 2986639399.024304 & 0.0000 \\
\hline
\end{tabular}

Cross-section random effects test equation:

Dependent Variable: EU

Method: Least Squares Panel

Date: 12/20/20 Time: 12:09

Sample: 20102018

Periods included: 9

Cross-sections included: 33

Total panel (balanced) observations: 297

\begin{tabular}{ccccc}
\hline Variable & Coefficient & Std. Error & t-Statistic & Prob. \\
\hline C & 266669.2 & 269292.7 & 0.990258 & 0.3230 \\
LOG(EG) & -76284.65 & 43647.54 & -1.747742 & 0.0817 \\
LOG(WAGE) & 53004.28 & 19610.75 & 2.702818 & 0.0073 \\
\hline
\end{tabular}




\begin{tabular}{lcll}
\hline \multicolumn{3}{c}{ Effects Specification } \\
\hline Cross-section fixed (dummy variables) & & \\
R-squared & 0.959228 & Mean dependent var & 121364.6 \\
Adjusted R-squared & 0.953937 & SD dependent var & 175748.9 \\
SE of regression & 37719.68 & Akaike info criterion & 24.02405 \\
Sum squared resid & $3.73 \mathrm{E}+11$ & Schwarz criterion & 24.45934 \\
Likelihood logs & $-3532,572$ & Hannan Quinn Criter. & 24.19832 \\
F-statistics & 181.2941 & Durbin-Watson stat & 1.062635 \\
Prob(F-statistic) & 0.000000 & & \\
\hline
\end{tabular}

Source: Data processed output, 2021

The probability value for the Hausman test is 0.00 , according to the results of data analysis. This probability value $(0.000 .05)$ is less than alpha. This suggests that the fixed effect approach is the optimal method to use. The fixed effect technique is known to be the best acceptable strategy for estimating the panel data regression model based on the findings of the Chow and Husman tests. The fixed effect technique is the result of panel data regression analysis, as shown in the table below.

Table 4. Panel Data Regression Analysis Results

Dependent Variable: EU

Method: Least Squares Panel

Date: $12 / 20 / 20$ Time: $12: 12$

Sample: 20102018

Periods included: 9

Cross-sections included: 33

Total panel (balanced) observations: 297

\begin{tabular}{lcccc}
\hline \multicolumn{1}{c}{ Variable } & Coefficient & Std. Error & t-Statistic & Prob. \\
\hline C & 266669.2 & 269292.7 & 0.990258 & 0.3230 \\
LOG(EG) & -76284.65 & 43647.54 & -1.747742 & 0.0817 \\
LOG(WAGE) & 53004.28 & 19610.75 & 2.702818 & 0.0073 \\
\hline \multicolumn{5}{c}{ Effects Specification } \\
\hline Cross-section fixed (dummy variables) \\
R-squared & 0.959228 & Mean dependent var & 121364.6 \\
Adjusted R-squared & 0.953937 & SD dependent var & 175748.9 \\
SE of regression & 37719.68 & Akaike info criterion & 24.02405 \\
Sum squared resid & $3.73 \mathrm{E}+11$ & Schwarz criterion & 24.45934 \\
Likelihood logs & $-3532,572$ & Hannan Quinn Criter. & 24.19832 \\
F-statistics & 181.2941 & Durbin-Watson stat & 1.062635 \\
Prob(F-statistic) & 0.000000 & & \\
\hline & Source: Processed data, 2020
\end{tabular}

Based on the results of the data analysis of the educated unemployment model on economic growth and wages, the panel data regression equation can be written as follows:

euit $=-1$ egit +2 wageit +

euit $=266,669.2+76,284.65$ egit +53.004 .28 wageit

The constant value is $266,669.2$ indicates that the value of the dependent variable before or without is influenced by the independent variable. This means that the average number of educated unemployed in the provincial government in Indonesia without being influenced by 
economic growth and wages is 266,669 people. The regression coefficient of economic growth variable (X1) is 76,669.65 which is negative, indicating that there is Economic expansion has a detrimental impact on educated unemployment. This suggests that a $1 \%$ rise in economic growth will result in a reduction in educated unemployment. by 76,669 peopleassuming other variables do not change (ceteris paribus).

The relapse coefficient of the compensation variable (X2) is 53.004.28 which is positive, demonstrating a positive impact of wages on taught joblessness. This implies that in case compensation increment by $1 \%$, it will increment instructed joblessness by 53,004 individuals expecting different factors don't change (ceteris paribus). Based on the results of data analysis, it is known that the R-squared value is 0.9592. This shows the magnitude of the influenceeconomic growth and wages on educated unemployment is $95.92 \%$ and the remaining $4.08 \%$ is influenced by other variables that are not included in the research model.

\subsection{The Effect of Economic Growth on Educated Unemployment}

This investigation discovers that monetary development has a huge adverse consequence on taught joblessness, implying that the higher the financial development, the informed joblessness will likewise diminish. With Thus it can be said that growth The economy affects the unemployment rate in an area. The higher the economic growth in an area, the higher the opportunity to develop for companies and the creation of job opportunities for the people of certain regions. In addition, an increase in economic growth Because increased GRDP allows for increased production capacity, it is projected that GRDP will be able to absorb labor in the region. This means that a drop in a region's GDP might be linked to a high number of unemployed people in that location.

To see the connection between monetary development and joblessness utilizing Okun's Law. This law clarifies that there is a negative connection among joblessness and GDP. The hypothetical premise of The connection that Okun studies is established with the understanding that more work approaches more labor and products. As indicated by Arthur Okun, when the genuine development rate is high, the joblessness rate falls, and when the genuine development rate is low or even regrettable, the joblessness rate increases. Soylu (2018). At the point when the economy goes into a downturn, it very well may be seen that joblessness increments [14]. Because employed labor produces goods and services while unemployed labor produces nothing,

Okun's Law is a reminder that the factors that determine the business cycle in the short run are different from the cycles in the long run. Short-term movements in GDP are highly correlated with labor force utilization. The decline in the production of goods and services that occurs during a recession is always associated with an increase in the number of unemployed. And vice versa if economic growth increases, the production of goods and services also increases so that it will create job opportunities to take advantage of the labor force and will reduce unemployment [1]. The findings of this study are relevant to the findings of previous research which has prove that economic growth negatively affects unemployment [18]; [19]; [20]; [9]; [10]; [11]; [12]; [14].

\subsection{The Effect of Wages on Educated Unemployment}

Wages have a substantial beneficial effect on educated unemployment, according to this

study, with the greater the salary level, the higher the educated unemployment rate. educated unemployment rate. The study found that wages measured from the provincial minimum 
regional wage (UMR) turned out to be one of the variables that affect the level of educated unemployment, where the higher the UMR level set by the provincial government will increase the number of educated unemployed because the provincial government's policy of increasing the UMR will certainly make companies are rethinking to accept new employees so that they delay accepting new workers and prefer to take advantage of existing employees which of course will result in an increasing number of educated unemployed.

The high level of wages received by workers depends on the shape of the labor market. In a perfectly competitive market situation, if wages were low many workers would not work. Conversely, the supply of labor will increase if the wages offered are high. The minimum wage tends to increase every year in line with the increase in real wages. The increase in the minimum wage is expected to trigger employment so that it can reduce unemployment, especially educated unemployment. Joblessness made by wage inflexibility due a change between the quantity of laborers who need work and the quantity of occupations accessible. Notwithstanding, what happens is that the expansion in the pay level makes the inventory of work increment, in this way lessening the interest for work. Therefore, there is an overflow of work or joblessness. The reasons for wage unbending nature include: the lowest pay permitted by law guidelines, worker's guilds and compensation effectiveness [1].

Wages will also have an impact on the level of employment and unemployment, the application of a minimum wage in each Regency/City will actually reduce the level of demand for labor which in turn will increase the number of unemployed. The application of the minimum wage, especially for a country with a large population such as Indonesia, will result in an increase in unemployment. Open unemployment occurs in the younger generation who have just finished their education trying to find work in accordance with their wishes. Their desire is to work in the modern sector or in the office and with a fairly high wage. To get that opportunity they are willing to wait a long time. This is what causes the tendency of high unemployment rates [15]. The basic assumption of classical economics is that the economy always exists in a state or condition of full employment. Namely that who wants to work will get a job and companies that need labor will get the desired amount. So the unemployed are people who are deliberately unemployed [17]. The findings of this study support earlier studies indicating that wages have a favorable impact on productivity unemployment [20]; [21]; [22]; [23].

\section{Conclusion}

In view of the consequences of exploration that has done, it tends to be inferred that monetary development significantly affects taught joblessness. SThe higher the economic growth, the educated unemployment will also decrease. With Thus it can be said that growth The economy affects the unemployment rate in an area. The higher the economic growth in an area, the higher the opportunity to develop for companies and the creation of job opportunities for the people of certain regions. This study also found that wages have a strong positive impact on educated unemployment, i.e., the higher the pay level, the greater the educated unemployment rate. The research found that wages measured from the provincial minimum regional wage (UMR) turned out to be one of the variables that affect the level of educated unemployment, where the higher the UMR level set by the provincial government will increase the number of educated unemployed because the provincial government's policy of increasing the UMR will certainly make companies are rethinking to accept new employees so that they delay accepting new workers and prefer to take advantage of existing employees 
which of course will result in an increasing number of educated unemployed. In this study, namely the influence of economic growth and educated unemployment wages, the suggestions that can be put forward are as follows:

a. It is hoped that stakeholders will always increase economic growth by opening up job opportunities in the province

b. It is hoped that the stakeholders will always calculate the standard of living in their respective regions wisely so that workers and employers alike benefit.

c. Given the limitations of the variables in this study, it is hoped that further research is expected to consider other variables but are still related to the theme of this research.

\section{References}

[1] Mankiw, N. Gregory. Macroeconomics. Worth Publisher, New York (2010)

[2] Tobing, Elwin. Unemployment of Educated Workers. Rineka Cipta, Jakarta (2005)

[3] Elfindri and Bachtiar, Nasri. Labor Economics. Padang: Andalas University Press (2004)

[4] Adrimas. Development Planning: Theory, Implementation and Problems. Andalas University Press, Padang (2012)

[5] Samuelson, Paul and Nordhaus, William D. 2004. Macroeconomics. Subtitles: Gretta, Theresa Tanoto, Basco Carvallo, Anna Elly. Jakarta: Educational Global Media

[6] Denburg, Thomas F. 1985. Macroeconomics. McGraw-Hill, Inc., New York.

[7] Soegner L., Stiassny A. (2002). An Analysis on The Structural Stability of Okun's Lawa Cross-Country Study. Journal of Applied Economics, 14, 1775-1787.

[8] Moosa, IA 2008. Economic Growth and Unemployment in Arab Countries; Is Okun's Law Valid. International Conference on "The Unemployment Crisis in the Arab Countries", 17-18 March 2008, Cairo-Egypt.

[9] Agifi, Elsana and Malaj, Visar. Impact of Economic Growth on Unemployment in Republic of Macedonia. International Journal of Economics, Commerce and Management. Vol. IV, Issue 1, January (2015)

[10] Makun, Keshmeer and Azu, Nnanna. Economic Growth and Unemployment in Fiji: A Cointegration Analysis. International Journal of Development and Economic Sustainability. Vol.3, No.4, pp.49-60, August (2015)

[11] Banda, Handson. Hlanganipai, Ngirande. Fortune Hogwe. The impact of Economic Growth on Unemployment in South Africa: 1994-2012. Investment Management and Financial Innovations, Volume 13, Issue 2, (2016)

[12] Schubert, Stefan F and Turnovsky, Stephen J. 2017. Growth and Unemployment: Short-run and Long-run Tradeoffs. Jjournal of Economic Dynamics \& Control (2017), DOI: $10.1016 /$ j.jedc.2017.11.003

[13] O'Nwachukwu, Chinadu and Increase. 2017. Dterminants of the Rate of Unemployment in Nigeria. International Journal of Information Research and Review. Vol. 04, Issue, 01, pp.3593-3595, January, 2017

[14] Soylu, zgur Bayram. smail akmak. Fatih Okur. Economic Growth and Unemployment Issue: Panel data analysis in Eastern European Countries. Journal of International Studies, 11(1), pp. 93-107 (2018)

[15] Gilarso, T. Introduction to Macroeconomics (Pert Edition). IKAPI, Yogyakarta (2007)

[16] Kadarisman. (2012). Compensation Management. Jakarta: Rajawali Press. 
[17] Wirakartakusumah, MA (1998). Development of the Food Industry in Indonesia. Food. Volume II (5). IPB. Bogor

[18] ah-Boateng, William. 2013.Determinants of Unemployment in Ghana. African Development Review, Vol. 25, No. 4, 2013, 385-399

[19] bah-Boateng, William. Unemployment in Ghana: A Cross SectionalAnalysis From Demand and Supply Perspectives. African Journal of Economic and Management Studies. Vol. 6 No. 4, 2015. pp. 402-415 (2015)

[20] Junaidi, F. The effect of education, wages and employment opportunities on educated unemployment in Jambi Province. Resource and Environmental Economics, 5(1), pp. 26-32 (2016)

[21] Ryan, RA, \& Istiyani, N., \& Hanim, A. Analysis of the Effect of Economic Growth, Number of Labor Force and Regional Minimum Wage on Educated Unemployment in East Java. Development Economics Study Program, Faculty of Economics and Business, University of Jember (UNEJ), IV(2), pp. 187-191 (2017).

[22] Warda, H., \& Nasri, B. Analysis of the Effect of Inflation, Economic Growth and Wages on Educated Unemployment in Indonesia. Journal of the Faculty of Economics, Andalas University, Padang, pp. 1-20 (2015).

[23] Hajji, MS, \& Nugroho, SBM. Analysis of GDP, Inflation, Provincial Minimum Wage, and Literacy Rate on Open Unemployment Rates in Central Java Province 1990-2011. Diponegoro Journal of Economics, 2(1998), pp. 1-10 (2013)

[24] Central Bureau of Statistics. Executive Summary of Employment Information 2018. BPS West Sumatra Province (2018)

[25] Sukirno, Sadono. Introduction to Macroeconomic Theory. Third Edition. Rajawali Press, Jakarta (2011) 